\title{
Restorative pathways after mass environmental victimization: Walking in the landscapes of past ecocides
}

OÑAT SOCIO-LEGAL SERIES VOLUME 10, ISSUE 3 (2020), 664-685: PRACTICES OF MEMORIALIZATION AND THE PROCESS OF SOCIAL RECONSTRUCTION DOI LINK: HTTPS://DOI.ORG/10.35295/OSLS.IISL/0000-0000-0000-1044

RECEIVED 15 OCTOBER 2018, ACCEPTED 20 MARCH 2019

\section{GEMA VARONA* (D)}

\section{Abstract}

Departing from the parallelism between large-scale human rights violations and the complex notion of ecocide, some conceptual remarks will be drawn within the realm of green victimology and restorative justice. By questioning the frameworks of victimhood and the irreversibility of ecocide, some conclusions about the meaning of informal practices of memorialization in mass victimization can be discussed. To illustrate these ideas, the Prestige case in Spain will be briefly presented as a case study.

\section{Key words}

Green victimology; environmental crime; ecocide; memorialization; restorative justice

\section{Resumen}

Partiendo del paralelismo entre las violaciones de derechos humanos a gran escala y la compleja noción de ecocidio, se realizarán algunas consideraciones conceptuales dentro del campo de la victimología verde y la justicia restaurativa. Al cuestionar los marcos de la victimidad y de la irreversibilidad del ecocidio, se debatirán algunas conclusiones sobre el significado de ciertas prácticas informales de memorialización en procesos de victimización en masa. Para ilustrar estas ideas se recurrirá de forma sucinta, como caso de estudio, a las consecuencias del Prestige en España.

\section{Palabras clave}

Victimología verde; delincuencia medioambiental; ecocidio; memorialización; justicia restaurativa

\footnotetext{
* Gema Varona is senior researcher at the Basque Institute of Criminology, University of the Basque Country. Contact details: Centro Carlos Santamaría Zentroa, Elhuyar Plaza, 2. 20018 - San Sebastián. Spain. Email address: gemmamaria.varona@ehu.eus
} 


\section{Table of contents}

1. Introduction: the green perspective of victimology in the so-called Anthropocene era

2. Environmental crime and ecocide in the framework of large-scale rights abuses, practices of memorialization and social reconstruction

2.1. The invisibility of environmental crimes and harms.........................................66 667

2.2. Naming extreme forms of environmental harms: ecocides ..................................6 668

2.3. Who are the victims, the victimizers and the bystanders committing serious

harms against the environment?

3. The case of the Prestige as ecocide: invisible victimization bubbling to the surface. 671

4. Reimagining restorative justice as wounded landscapes: memorials as route marks

4.1. The wounded landscape after the Prestige

4.2. Emerging narratives by walking in the landscapes of past ecocides: insights

about environmental risks from restorative justice

5. A less anthropocentric justice? Ways of reviving from environmental harms .........676 676

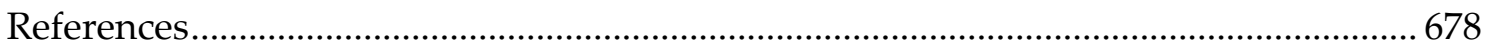

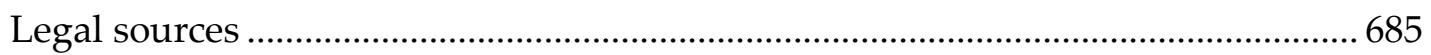

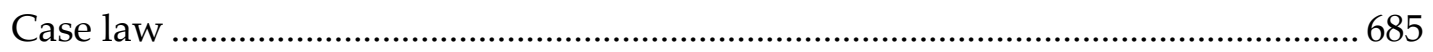




\section{Introduction: the green perspective of victimology in the so-called Anthropocene era}

This paper will review some concepts elaborated upon by green victimology (Davies 2017) and reflect on how some of them can be put in with the context of the literature on atrocities or mass victimization and, more specifically, with memorialization studies and narrative models to frame not only victimization but also reparation (Hall 2013, Hoondert et al. 2018). These ideas will be illustrated with the case study of the Prestige tank disaster that occurred in Spain in 2002. Memorials of that event and its consequences will be considered as part of possible informal restorative justice practices reflecting tensions among different stakeholders.

The noun "justice" will be re-examined in relation to the claim of a less anthropocentric justice that takes non-human victims into account (Flynn and Hall 2017, White 2018, Whyte 2018). This idea is specially challenging because most of the harms we are referring to might be also classified under the category of "irreparable". Here is precisely where memory and the different examples given below of memorialization practices dedicated to the Prestige come to the forefront. However, many complexities remain in relation to what kind of memory we are referring to, who the stakeholders are and what the purpose of memorialization might be.

After it originated from the green criminology (Lynch 1990, Lynch and Stretsky 2003, South 2007, Johnson 2017, Brisman 2017, Nurse 2017) developed in the nineties to approach environmental crimes and harms (Ruggiero and South 2010), green victimology gained momentum in the early 2000s by studying the victimization derived "from environmentally destructive activities or omissions" (Hall 2017, p. 2). This marginal perspective or theoretical approach has been expanded beyond Anglo-Saxon scholars (Hall and Varona 2018), and it is currently attached to criticism towards the victimizing role of the state and its alliances with large corporations. In this area, contributions by ecofeminism (Groombridge 1998, Puleo 2018, Varona forthcoming 2020) and the critical studies against colonialism, racism and capitalism (Kirby and O'Mahony 2018, Liodakis 2018) can add more understanding to the topics studied by green victimologists (Bullard 1994).

The perspective of green victimology embodies an interdisciplinary field where other frameworks such as political ecology or environmental ethics coexist. It is also connected to cultural victimology (Hall 2017, Mythen and McGowan 2017), that is, the cultural understanding of victimhood and of the processes of victimization and reparation. This victimology includes how environmental harm and its victims are conceived, constructed and reproduced in the media and in the cultural climate. This climate helps make those victims invisible, either by not recognizing their suffering or the impact of environmental harm or by justifying the harm done or not depicting it as unjust. This usually happens when nature is portrayed in our society as a commodity within patterns of consumption or as an instrument of political contest over space and resources (Hall 2014), where the use of scientific criteria seems central though insufficient.

Green victimology considers the lessons of zemiology, the study of social harms (Feinberg 1987, Pemberton 2016, Hillyard and Tombs 2017, Brisman and South 2018), which is mostly done in criminology in relation to white-collar crime, corporate crime 
and crimes of the powerful (Tombs and Whyte 2015). More recently, social harm also refers to environmental harm, including a variety of results and endangering behaviours labelled as crimes, administrative offences or unethical activities. This might entail forms of mass victimization with accumulated effects on human and non-human victims. The concern for this kind of victimization happens in a geological period defined by some scientists, following Paul Crutzen's term, as "Anthropocene", notwithstanding the scientific disputes about this concept (Mann and Wainright 2018). The idea behind "Anthropocene" is that we have never witnessed such a global and extreme impact created by humans on the ecosystems. This awakens the problem of responsibility over facts such as climate change (IPCC 1997, NASA Global Climate Change n.d.), cruelty towards animals and the decrease in biodiversity.

Thus, as a kind of triangulation, the avenues of green victimology, memorialization and restorative justice come together in this paper to conceptualize the possibilities of reparation for victims of ecocide conceived as a gross violation of rights. Among those possibilities informal and spontaneous practices allow us to think of steps towards the need of a cultural change in relation to the visibility of this sort of victimization.

\section{Environmental crime and ecocide in the framework of large-scale rights abuses, practices of memorialization and social reconstruction}

\subsection{The invisibility of environmental crimes and harms}

Despite different regulations in different countries, environmental crime usually includes behaviours such as the illegal taking or trading of non-human species (flora and fauna), pollution offences, and the transportation of banned or toxic substances (radioactive or hazardous material) (Hall 2017). Environmental crimes and harms imply invisibility in terms of potentialities, agents' accountability, diffuse victimization and cultures of consumption, endless progress and inevitability. This invisibility contrasts with the magnitude of the impact these harms cause (Halsey 2004, Ruggiero 2013).

First, there is an inherent invisibility in environmental crime due to its effects in time, many being not visible at the beginning of its causation. Its victims might not have even been born in what can be called an anticipated or potential victimization process. This makes it difficult to show or claim suffering and introduces problems of legal evidence into the causes and consequences which usually structure criminal accountability (Lacey and Pickard 2018).

Second, the traditional positivist notion of crime does not consider the characteristics of environmental offences such as "white-collar crimes" and "crimes of the powerful", even though some of them might not always fit into these criminological categories. Criminal justice systems progressively support the idea of the criminal liability of corporations, but the reality is that companies are in positions of power and in connection to politics and the economy. This makes it very difficult to honestly defend the idea of equality of arms in court. Many defendants of corporations accused of environmental crime might be represented by prestigious criminal law professors who might have in front overloaded prosecutors with scarce resources and facing political and economic pressures (Benson and Cullen 1998). The NGOs or associations representing the claims of victims are also in a situation of asymmetry in relation to the 
actual power they possess to bring and contrast evidence, and yet some victories might be recalled (Solnit 2016).

Third, the victims of environmental crimes and harms are greatly diverse (human and non-human, usually unheard or without any voice). In relation to humans, the victims might be the whole global society, in what is known as diffuse victimization. Environmental crimes on a large scale hold a transnational character that is very difficult to criminalize as such despite international legal norms and controls. This is the case of climate change through deforestation and global warming, biodiversity threats (species extinction and genetic modification), and waste and pollution in general. In addition, there is a lack of criminological theorization and research on the non-human victims of corporations (Mazzucato 2016). This opacity contributes to a lack of awareness in a vicious circle where legal notions, such as the 29/2102/EU Directive on the rights of victims, keep restricting the concept of victims to natural persons.

Finally, we are faced with relevant structural and cultural issues. There exists the idea that progress, in the form of extreme capitalism, is desirable and inevitable (Bouveresse 2017). The belief in unlimited growth in a limited planet inhabited by many beings creates an illusion of endless growth. Paradoxically, and adapting Stephen Pinker's (2011) terms on the civilizing process in our societies, we can talk of a predatory or practical violence, with dominance and ideology playing a complementary role, where the "better angels of our nature" (empathy, self-control, moral sense and reason) do not seem to play a relevant role in relation to how we treat other species and the ecosystems. Again, structural violence reveals itself as a slow and disregarded form of violence (Rivera 2014) where empathy or moral engagement does not seem to work in the same manner as with interpersonal relations within a state or community. Harari (2018, p. 224) contends that the sense of justice is more difficult to be comprehended in complex relationships between millions of human and non-human beings across entire continents and oceans. Due to the harms already provoked, a progressive concept of justice could be identified in the notions of degrowth and conservation (Pineault 2018).

\subsection{Naming extreme forms of environmental harms: ecocides}

In a legal theoretical construction, corporations or states can be conceived of as victims or harmed entities at least in terms of civil liability. However, this is not the case with other entities such as rivers, mountains or other ecosystems. Indigenous legal activism defends the rights of nature in relation to their cultural rights and cosmologies. In September 2008, Ecuador became the first country in the world to recognize the constitutional rights of nature itself, including the right to its restoration. Some other countries, such as New Zealand, India and Colombia, have followed this trend in different ways (Cano 2018). This conceptualization has been defined as eco- or biocentrism. Again, when talking about the language of law, beyond the philosophical debate, tension remains around the clash of rights and their limits: to what extent can the instrumental use of nature by human beings (mainly in the form of corporations) for economic reasons be above those rights of nature? Where are the reasonable limits in every socio-historical and economic context? How can we be assured that the chosen option has caused the minimum possible harm (Whyte 2018)? 
As the studies on zemiology quoted above demonstrate, the notion of social and ecological harms, instead of crimes, include a more dynamic, collective and nonanthropocentric perspective, stressing the diversity of psychological, material, economic, and the cultural impacts on different beings and entities. Combining the terms of ecology and genocide, when those impacts are extreme, a new term has been coined: ecocide (White and Kramer 2015). It holds an activist objective to call attention to the gross violation of (human and non-human) rights and the health and well-being of species and systems (Whyte 2018). The biologist Arthur W. Galston adopted this term in 1970 to criticize the use of Agent Orange during the Vietnam War. In 1972, the term was used by Olof Palme during the UN Conference on the environment. Almost twenty years later, in 1990, the criminal code of Hanoi included destroying nature in peace or war periods as a crime against humanity (Drumbl 1998, Higgins 2010, Soler 2017). The debates on ecocide reached the International Criminal Court in 2002 (Wattad 2009). The Rome Statute does not employ this term, and it includes only the destruction of the environment by private or public agents in war time in its article 8(b)(iv). However, some scholars have proposed changes in article $7(\mathrm{l})(\mathrm{k})$ of the Rome Statute so that ecocide is expressly included (Drumbl 1998, Ruiz Rodríguez 2003, Wattad 2009, Hadden 2015).

More recently, in 2010, the University of London has continued the debate on ecocide and the possibilities of restorative justice (Rivers 2012). In October 2016, a citizen's tribunal took place in The Hague to debate ecocide (Cabanes 2017) in relation to the Monsanto herbicides and, even without binding normative status, the decision of this tribunal concluded that:

[with the need to] clearly assert the protection of the environment and establish the crime of ecocide (...) it seems that Monsanto knew how its products would be used and had information on the consequences for human health and the environment. The Tribunal is of the view that, would the crime of Ecocide be added in International law, the reported facts could fall within the jurisdiction of the International Criminal Court (ICC).

Promoting the use of the name and awareness around ecocides, understood as "causing serious damage or destroying the environment, so as to significantly and durably alter the global commons or ecosystem services upon which certain human groups rely" (Paul 2017), different activist digital platforms, such as eradicatingecocide.com have contributed to the construction of new forms of victimhood to enhance cultural and social recognition of the condition of being a victim (Hadden 2015).

Thus, ecocide can be defined as an attempt to label as criminal the human activities that destroy the well-being of ecosystems and species (Shiva 2017). This line of argument brings another question: if justice and reparation have to be claimed after ecocide, who is representing the interest of ecosystems, animals and plants? In what sense can we translate classical and recent victimological terms to this field, such as victimization experience; narratives; recovery; restoration; the need for well-being, acceptance, respect, safety, self-efficacy and meaning (Kirchhoff et al. 2013); or the rights of information, protection, support, and access to justice, reparation and humane treatment; the avoidance of secondary victimization; or the promotion of reconciliation? Is it possible to understand as elements of justice for non-humans the issues of truth, acknowledgement/recognition, accountability and non-repetition? 
Obviously, all those concepts need to be reinterpreted. For example, the notions of ignorance and accountability in this field go beyond legal terms as posed by Harari (2018, p. 225):

... today, the really important arguments about theft concern completely different scenarios. Suppose I invest $\$ 10,000$ in shares of a big petrochemical corporation, which provides me with annual 5 per cent return on my investment. The corporation is highly profitable because it does not pay for externalities. It dumps toxic waste into a nearby river without caring about the damage to the regional water supply, to the public's health, or to the local wildlife. It uses its wealth to enlist a legion of lawyers who protect it against any demand for compensation. It also retains lobbyists who block any attempt to legislate stronger environmental regulations. Can we accuse the corporation of 'stealing a river'? And what about me personally?

\subsection{Who are the victims, the victimizers and the bystanders committing serious harms against the environment?}

In trying to respond to the above questions, individual, social, economic, political and cultural issues emerge. Human and non-humans (animals, plants and bio-systems) are affected even though that harm might not be criminalized as such and the rights to nonhumans might not be recognized, although article 13 of the EU Lisbon Treaty recognizes animals as sentient beings and current scientific debate since the seventies discusses this question for flora (Tomkins and Bird 1973). In exceptional cases when these rights are acknowledged, such as the rights of nature (pachamama) in the Ecuadorian Constitution since 2008, the right of restoration is mentioned. As already explained, this trend is known as bio or eco-centrism. However, it should not be thought of as the complete opposite of anthropocentrism. Even if signalizing the risk of the instrumentalization of the environment by certain power groups, the notion of centrism does not capture the complexities and diversity of interdependent interests at stake (Burger 2003, White 2018).

Linked to the complexities of the consequences produced in environmental harms and ecocides is the lack of awareness (for human and non-humans), helplessness, and sometimes the acceptance of the harm by bystanders and victims themselves (Rothe and Kauzlarich 2017). As posed by Harari (2018, p. 225): "The system is structured in such a way that those who make no effort to know can remain in blissful ignorance, and those who do make an effort will find it very difficult to discover the truth". This makes easier to silence disadvantaged groups even though the global impact of environmental harm would require a greater number of viewpoints to be considered.

The ignorance, intolerance and denial (Cohen 2001, Taibi Cicaré 2018) are reinforced by the wording, interpretation and enforcement of the law where few penalties are finally imposed, and when imposed, they represent the tip of the iceberg where hidden victimization constructs most of the unseen problem. Moreover, the notion of ideal victims, in popular and legal culture, related to victimhood is difficult to translate to this sort of harms (Davies 2018). In what sense can we consider victims as innocent, respectful, vulnerable and related to the offender responsible for the environmental harm or ecocide? Inside one state or among states, nature and animals have been traditionally conceptualized as disputed resources, not victims. 
These theoretical challenges affect both public knowledge and the expertise of victimological knowledge and its professionals. Concern about individualities, posttraumatic stress disorder and personal narratives is translated into (human and nonhuman) collectivities, collective trauma (McGarry and Walklate 2015) and geographical narratives that pertain to the field of natural science, history, anthropology, geography and economy more than to the psychology usually occupying a great part of the academic production and practical intervention in classical victimology.

\section{The case of the Prestige as ecocide: invisible victimization bubbling to the surface}

In order to illustrate how difficult (or not) results applying those notions mentioned above to a mass environmental harm that has been labelled by some authors as ecocide, in this section we briefly and generally describe the case of the Prestige. The Prestige was a 26-year-old structurally deficient oil tanker sunk after a thunderstorm in Galizia (Spain) at the end of 2002. In relation to victim risk and impact, the Prestige case represents an example of ecocide where some ambiguities and manipulation were used by certain economic and political stakeholders who, at some point, were signalized as accountable (Caballero and Soto-Oñate 2017).

The sinking of the Prestige tanker has been presented as an example of state-corporate crime and ecocide (Bernat and Whyte 2017) where a certain connivance existed (Kauzlarich et al. 2001, Rivera 2014, Hall 2018) in a permissive legal system favouring privilege, impunity structures and the lack of accountability (Bernat and Whyte 2017). When evaluating the spill risk and its possible consequences, the mistaken Spanish government's decision to try to remove the tanker out of its territorial waters augmented the final costs in what was later considered a wrong risk assessment (Mairal 2008).

The Prestige tanker poured more than 77,000 tonnes of fuel-oil, polluting more than two thousand kilometres of coast, including French and Portuguese shores. The spill killed numerous ecosystems and species (among them, more than 200,000 sea birds). The sinking of the Prestige had a severe impact on human and non-human health and the economy (in terms of fishery and tourism). The costs of cleaning the black tide went beyond 107 million Euros (Bernat and Whyte 2017, p. 73). The impact was unequally distributed upon certain segments of the population, such as small fishermen and fisherwomen who were already in a precarious labour situation and under duress from different conditions or sections of inequality.

For all the reasons mentioned above, the Prestige case is considered the worst oil spill in the history of Spain and Europe. The administration of justice response came many years after, in 2013. That year, the Provincial Court of A Coruña condemned the captain of the oil tanker for disobedience but not for an ecological crime. This was surprising because the Spanish criminal code conceives of ecological crimes beyond the concept of anthropocentrism. In 2016, in an appeal, the Spanish Supreme Court did recognize the commission of an ecological crime by interpreting articles 325 and 327 of the Spanish criminal code defining that sort of crime. The Supreme Court understood the principle of "polluter pays" in an extensive way according to European Union legislation. Thus, it estimated the costs caused beyond the limits of civil liability. This judicial decision made direct responsible the insurance company of the tanker and it declared the 
subsidiary civil liability of the company owner of the tank (Caballero and Soto-Oñate 2017).

The tanker was built in Japan but owned by a company located in Liberia and registered in the Bahamas and operated in Greece. The society that classified its safety was from the United States. The oil belonged to a Swiss company. The insurance company was British. However, the captain and the company owner of the tank declared their insolvency. At the same time the judicial process against ABS, the classification company in charge of certifying the safety of the tanker, failed (Bernat and Whyte 2017). In addition, as mentioned above, in the 2016 decision of the Supreme Court, the Steam Ship Owners Mutual Insurance Association (The London P\&I Club), as civil liability insurer, was held directly liable up to the policy limit (USD 1,000 million). This has been ratified by the Spanish Supreme Court judgement 668/2018, of the $19^{\text {th }}$ of December, 2018, which dismisses the appeal of The London P\&I Club and settles definitively the compensation for the damages in more than 1,500 million euros. In this judicial decision the appeals of the public prosecutor and the French state, among others, against the civil liability judicial decision of the Provincial Court of A Coruna, of the 15th of November of 2017 which executed the 2016 Supreme Court decision, are accepted. In the 2018 Supreme Court decision it is made clear that it has to be the judge of the Provincial Court executing the judgement the one who claims this execution in the United Kingdom, where The London P\&I Club has its headquarters. ${ }^{1}$

In any case, the Spanish state has already paid for the damages caused to third parties, and it has minimally compensated for the costs caused to the majority of the economic sectors affected by the spill (Caballero and Soto-Oñate 2017, p. 218).

In line with the previous sections of this article on the invisibility of this sort of harm, we can conclude that the Prestige ecocide caused a tremendous collective and long-term impact (Arroyo et al. 2017) on the well-being of species and eco-systems. However, being entangled in international and internal regulations, mistaken decisions by the Spanish government, and unethical company practices, full criminal and civil liability was never found in relation to the responsible companies. Spanish, as well as Portuguese and French, citizens ended up suffering, cleaning and paying for something they did not provoke (Verdú 2003). Thus, we can say that, together with non-human victims, they were simultaneously victims and reparation agents. This view can bring some reflections on agency and empowerment (Simonsen 2017). However, even if the civic movements against the ecocide were relevant (for example, with the social platform Nunca MáisGaliza/Never Again Galizia), the media impact of this victimization created different and controversial political readings, ranging between empowerment from the bottom for the ecological cause, to political manipulation of victimhood and accountability (Sampedro 2003). Notwithstanding the remaining global impact, in terms of actual reparation, the most tangible effect after the ecocide was the changing of Spanish legislation to prevent the entrance of deficient oil tankers in territorial waters following the legislation of other countries in the European Union (Juste 2003).

\footnotetext{
${ }^{1}$ The fact that Spain has lost a case before the UK courts against The London P\&I Club and has won a very similar case before the Spanish Supreme Court causes an interesting conflict between two different outcomes.
} 


\section{Reimagining restorative justice as wounded landscapes: memorials as route marks}

\subsection{The wounded landscape after the Prestige}

Thus, many of the Prestige damages are irreparable or have not been fully and fairly repaired. Together with the notion of irreversibility of the deaths and destruction caused in 2002 and the years after, the notion of nature regeneration emerges. That regeneration can also be interpreted, at least for humans, as the duty to prevent similar cases by changing the social, economic and cultural relationships of production and trade that allow that kind of harm to occur. International standards on gross violations of human rights, such as the so-called Joinet principles, ${ }^{2}$ recognize the right of victims to truth, access to justice, reparation, memory and guarantee of non-recurrence, together with the duties of the states and other agents to be accountable for the harm caused.

Memorialization practices raising awareness for similar harms might be important for prevention and non-repetition. In the case of the Prestige, today the shores of Galizia have apparently recovered their beauty. However, different official and informal memorials, built mostly by popular initiatives along the coast, remind us of a wounded landscape. Those memorials create the possibility to bring the past to the present to stop for a moment and consider the idea of endless progress entailed with certain cultural forms of production and regulation by companies and states, respectively. For those who want to take the walk and be questioned in those natural landscapes, the memorials, as creative art forms, narrate that collective trauma and its suffering and resistance in complex ways (Di Ronco et al. 2018), with limits and potentialities, particularly when considering issues of accountability.

Those memorials on the site of the ecocide might convey more meaning than the only original piece of the tanker exposed in the Sea Museum of the city of Vigo (Galizia). Obviously, there have been memorialization practices in the form of commemoration days, exhibitions, poetry, scientific and historical books. In all of them, we can observe the raising of questions, usually posed by victims of severe crimes, such as why and how it was possible, the sense of impunity and the need for social reconstruction (Diz Otero and Lois González 2005).

The memorials on the site of the spill were also made to remember the work of the thousands of volunteers who helped to clean the spill, but their integration within the landscape allowed us to think beyond human lives and costs. Among those memorials, there is one especially significant for its creation process and size. It is situated by the cliff of Pedra da Boia and the sanctuary of A Barca, famous for its so-called magic stones. This memorial, titled The Wound, is a monolith constructed by the sculptor Alberto Bañuelos-Fourier. With a weight of 400 tonnes and 11 metres of height, it is made of granite, has a rectangular shape, and is broken in the middle. It is known as the largest

\footnotetext{
2 The Joinet principles were developed by Louis Joinet and approved in 1997 by the United Nations Commission on Human Rights in recognition of the rights of victims and the obligations of states in the fight against impunity when massive violations of human rights and international humanitarian law have taken place. See also the 2006 UN Basic Principles and Guidelines on the Right to a Remedy and Reparation for Victims of Gross Violations of International Human Rights Law and Serious Violations of International Humanitarian Law (Haldemann and Unger 2018).
} 
sculpture in Spain. Paradoxically it was financed by an insurance company and inaugurated by the criticized government of Galizia, one year after the spill. However, all these contradictions construct a form of memory integrated, many years later, within the landscape. In this sense, this memorial might function as a time gate to reflect on the possibilities of restorative memory defined as diverse practices being creative, reparative, voluntary, participatory, dialogic, interdisciplinary, dynamic and complementary to the criminal system and other forms of memorialization. These practices can be ephemeral or long-lasting. Restorative memory might involve victims, victimizers and communities in a non-essentialist definition that acknowledges accountability. It also entails the hidden victimization and the memory of the denial, indifference and oblivion. In doing this, creative language and narrative privilege might open new perspectives to fill some gaps towards emancipation from the abuse of power and inequality by making sense of the consequences of ecocide as an opportunity for bottom-up social transformation.

As mentioned before, the Recommendation $\mathrm{CM} / \operatorname{Rec}(2018) 8$ of the Committee of Ministers of the Council of Europe, concerning restorative justice in criminal matters, adopted on 3 October 2018, uses the term "victim" restricted to natural persons but also recognises the potential of restorative justice to identify and to address the interests of those affected by "harm" caused in victimization processes when there is a "basic acknowledgment" of that harm. The Recommendation states that the type, seriousness or geographical location of the offence should not, in themselves, preclude restorative justice from being offered at any stage of the criminal justice process, including postsentencing. The focus on reparation includes intangible forms of addressing the harm produced. The Recommendation aims "to encourage the development of innovative restorative approaches - which may fall outside of the criminal procedure". Some important principles indicated in this text are reparation and "avoiding domination". This last principle should reframe the principles of neutrality and confidentiality for restorative justice in environmental harms so that domination by perpetrators can be avoided (Hamilton 2017, Begum 2017).

\subsection{Emerging narratives by walking in the landscapes of past ecocides: insights about environmental risks from restorative justice}

We can try to deepen and extend the insights of previous research on restorative memory by applying them to new topics, such as ecocide, and to reflect on the basis of memorialization more generally. Restorative justice has much to do with symbolic issues relevant for ecocides as they express more abstract, collective, non-human, incommensurate and long-term harms. However, practices of restorative memorialization should acknowledge their limitations so that they are not thought of as a mere aesthetic or minor form of justice perpetuating inequality and abuses of power (Braithwaite 2002).

Walking and retracing through harmed landscapes, as a way of questioning any kind of social and economic progress, can entail an active personal and collective engagement where the relevance is the process (taking complementary steps towards a cultural change) and not so much the results. Walking involves the passing of time, necessary for experience where possibilities of emotional energy (Rossner 2011) and agonistic memory 
(Cento Bull and Lauge Hansen 2016) might be present. The passing of time in the long run also involves an intergenerational awareness where places become equivalent to time and relationships (Richardson 2017). Thus, memorialization identifies itself more with the tides or flows of every person and generation rather than storerooms in museums.

Within the field of narrative geography, these ideas are related to spatial narratives (Ryan et al. 2016). The geographical map is not the narrative, not even the memorial built. The narrative emerges by the experience of walking alone or in groups through those landscapes. Obviously, in every context, we can wonder who tells the story, how and what for. The memorial The Wound for the Prestige ecocide can work not only as a tourist attraction but as a narrative from which the walker might construct some meaning in the form of integration in a walked landscape where public knowledge and imaginative aspects come together. We can call it a memorable landscape in the sense of bringing to the present a past ecocide whose effects are apparently invisible now, in part for the power of recovery of nature. That territory becomes a legible landscape (Brinkhuijsen 2007) for a more complex and contested reading compared to one allowed by a mere visit in line with mass tourism. Space might function as a text to be experienced as a meta-narrative (Duncan and Ley 2013) where power relations are implicit. Again, power asymmetries notwithstanding, this landscape of collective traumatic memory might be read as enhancing remembrance for social transformation.

Sculptures and monoliths in the landscape work as physical reminders revealing how subjective and objective elements shape cultures of victimhood and power relationships. Restorative justice underlines the need for social compromise and involvement in dealing with harms. This is particularly relevant because public debate around ecological risks must be augmented by informed experts (Gibbs et al. 2009), but the risk of disempowerment and lack of agency should be considered by opening the debate to silenced voices.

By fostering the normative value of pluralism as well as the substantive value of epistemic diversity, the interpretive social sciences and humanities can assist in opening up public deliberation on climate change such that alternative questions, neglected issues, marginalized perspectives and different possibilities can gain traction for policy purposes. (Blue 2016, p. 67)

It is important "to contextualize the problems, materialities, and systems that are not readily apparent" (Liboiron 2018, p. 1). Scientific questions also imply social, cultural, economic and political questions, which are necessary to question the systems that allow its thinking as inevitable. Some results of so-called discard studies include landscapes that have been "left out, devalued, left behind, ruined" (Liboiron 2018, p. 3). Discard studies put the focus on the structures, not behaviours, sustaining practices of harm (and memorialization). Those structures imply different systems of measurement and imaginaries of risk codifying what is legally acceptable or dangerous for certain agents. This affects notions of human and ecological harm, uncertainties and scientific and public knowledge, usually thought as lacking expertise. According to Zahara (2018, p. 6):

Moving away from risk perception and towards public understandings of risk reorients researchers away from deficit model approaches and towards one of addressing locally 
identified problems. Doing so requires seeing public controversies not as the byproduct of people who don't understand a given issue, but as points of tension that highlight major discrepancies between public infrastructure and community understandings of harm and justice.

Restorative justice could allow a certain epiphany of the invisible "other" and might foster the initiative and participation of victims urging questions of agency in bottomup initiatives. This development does not imply an angelic vision on restorative memorialization practices. Those initiatives can either legitimize and internalize asymmetries of power or can contest them, perhaps as binding elements to resignify traumatic places and relationships with an individual, social, educative, proactive and preventive perspective. Restorative justice, beyond economic compensation or mere negotiation, might offer avenues for a more practical and symbolic redress that could account for the environmental victimization impact produced (Hall 2017). However, up to now, restorative justice has "failed to adequately incorporate notions of ecological and species justice" (Bryant 1995, Hall 2017, p.1).

\section{A less anthropocentric justice? Ways of reviving from environmental harms}

Walking in the landscapes of past ecocides permits one to create nuanced spaces where knowledge and the encounter with the (human and non-human) "other" can be promoted through ethical imagination and sensitive and self-critical dialogue, with the aim of a cultural reconstruction of the precarious value of different forms of life, acknowledging that the conflict of interests is inherent to life but not necessarily to the destruction of its many expressions.

Diffuse or collective victimization in ecocides expands in terms of generations and territories with a diversity of beings and entities harmed, that is humans, non-humans and the environment itself (Hall 2017, p. 2). This expansion means there is a need for a less anthropocentric (Zimmerman 1985) and more dynamic view of victimization (Hall 2017, p. 2). However, to a great extent, victimology itself as a discipline has been constructed on anthropocentric, personalized and individualized notions such as experience, risk, impact, needs, rights and narratives. This is also the case for restorative justice. For this reason, in this article, we have found it challenging to think about the limits of transposing classical victimological concepts to ecological victimization. In doing so, we have raised more questions than answers and the challenge to conceive otherness in a more radical way, relating restorative justice and the notion of ecological and interspecies justice (Rodríguez Goyes and Sollund 2018), remains.

Following certain approaches on "ecological well-being" by the United Nations Environment Programme (2018), we can go beyond the limited legal criteria to think in ecological or eco-justice terms (including the language of -environmental- rights) or even in terms of interspecies justice. Ecological harms go against the ecological wellbeing and holistic understanding of the interdependence between the environment and the different species in the globe (Riechmann 2017). Thus, nature and non-human species hold an intrinsic value (White 2013, 2018). In a more eco-justice perspective, environmental rights come to the forefront from the notion of ecological citizenship and 
the conceptualization of species justice where other non-humans can be conceived as victims.

Restorative justice aims to respond to the traditional claim of a more human and personalized form of justice, respecting diversity, relations and victim changes throughout time. Ecological and interspecies justice stresses the need of human duties, not only needs, and underline the challenge of envisioning the non-human "other". This task seems very complex in practice, and many questions remain, such as the meaningfulness of these restorative practices. In a context of lack of criminal sanctions for corporate crimes, if the role of punishment is not stressed, activists fear that the symbolic character of criminal law will not be used to agree on what is seriously harming the environment, species and society. We can wonder whether restorative justice can offer public validation for the wrongs committed and of the resulting victimization. ${ }^{3}$

Integrating different concepts on victims' interests, needs and rights functions as an interrupter of the tyranny of certain visions of progress to open space for slow social reconstruction. Public debate is needed in the definition of who represents those diverse and changing interests and the needs of non-humans and ecosystems, as actual survivors. Modern and critical victimology (Walklate 2017) has stressed the difficulties and invisibilities in relation to capturing the experiences of victimization by human beings, but they have not given significant clues on how to grasp the experiences of victimization by non-human entities, although some authors point out to agents concerned everyday with the care of the nature, animals and flora as divergent speakers from political, judicial and economic elites (Hall and Varona 2018).

The awareness of this kind of victimization, particularly the notion of what is included and excluded as harm, is important because excessively dramatic views on the ecological disasters produced in the Anthropocene era might preclude us from acting. If we take things as inevitable and beyond human action, a sort of inverted totalitarianism is fostered (Wolin 2008). Within the relevance of structures of power and cultures of atrocities against environmental victims (Ruggiero 2013), there could be hope for a dialectic between vulnerabilities created and the existing power relationships revealing the hidden and postponed harms as well as the will and social action fighting for the absence of devastation. That resistance is also worthy of memorialization (Rivera 2014). At some point, resistant collective behaviours might count: “Benjamin's angel tells us history is what happens, but the Angel of Alternate History tells us that our acts count,

\footnotetext{
${ }^{3}$ Although it is beyond the scope of this paper, the role of civil and administrative proceedings for purposes of participation and restoration in environmental issues should also be considered. See the UNECE Convention on Access to Information, Public Participation in Decision-making and Access to Justice in Environmental Matters, also known as the Aarhus Convention, and the Directive 2004/35/EC of the European Parliament and of the Council of 21 April 2004 on environmental liability with regard to the prevention and remedying of environmental damage. The degree of efficacy of these proceedings brings a further reflection to pose the question on whether it is really worth pursuing the path of criminal justice to protect non-human beings and the eco-systems. Moreover, the use of criminal law and the necessary standard of evidence bring always certain inequality. For example, the Prestige case ended up with a very controversial criminalisation of the captain for the sake of providing redress while other similar cases finish being acquitted in absence of a clear regulatory framework. In Captain Mangouras v Spain, 28-09-2010, the ECtHR found no violation of Article $5 \S 3$ (right to liberty and security) of the European Convention on Human Rights with regard to the pre-trial detention - with possibility of release on bail of three million euros - of the captain.
} 
that we are making history all the time, because of what doesn't happen as well as what does" (Solnit 2016, p. 71).

There is a promising future line of research by reframing the classical concepts of victimology in order to think of ecocide, memorialization and restorative justice. However, we should avoid a mere transplant of those concepts to the non-human victimization in ecological harms and bring more interdisciplinary debate to integrate it with notions of interspecies and ecological justice. Failing to do so would imply, again, an anthropocentric and instrumental vision that would lose the perspective of the whole and complex scenarios of this sort of victimization.

\section{References}

Arroyo, L., De Pablo, A., and Gimeno, J., 2017. Historical pollution in Spain: A powerful legal framework for a few past cases. In: F. Centonze and S. Manacorda, eds., Historical Pollution. New York: Springer, 265-306.

Begum, R.A.R., 2017. The potential of restorative justice in strengthening corporate governance framework. Internet Journal of Restorative Justice, 5 Year Celebration Special Issue [online], 2056-2985. Available from:

https://www.theogavrielides.com/product-page/the-potential-of-restorativejustice-in-strengthening-corporate-governance-frame [Accessed 20 March 2019].

Benson, M.L., and Cullen, F.T., 1998. Combating Corporate Crime: Local Prosecutors at Work. Boston: Northeastern University Press.

Bernat, I., and Whyte, D., 2017. State-corporate crime and the process of capital accumulation: Mapping a global regime of permission from Galicia to Morecambe bay. Critical Criminology [online], 25(1), 71-86. Available from: https://doi.org/10.1007/s10612-016-9340-9 [Accessed 20 March 2019].

Blue, G., 2016. Framing climate change for public deliberation: What role for interpretive social sciences and humanities? Journal of Environmental Policy $\mathcal{E}$ Planning [online], 18(1), 67-84. Available from: https://doi.org/10.1080/1523908X.2015.1053107 [Accessed 20 March 2019].

Bouveresse, J., 2017. Le mythe moderne du progrès. Marseille: Agone.

Braithwaite, J., 2002. Restorative Justice and Responsive Regulation. Oxford University Press.

Brinkhuijsen, M., 2007. Legible landscapes: the use of narratives in landscape design for leisure and tourism in Dutch cultural landscapes [online]. Conference paper. ASA Conference (Association of Social Anthropologists) Thinking through tourism, London. Available from:

https://www.researchgate.net/publication/40094813_Legible_landscapes the use of narratives in landscape design for leisure and tourism in Dutch cultural landscape [Accessed 5 May 2018].

Brisman, A., 2017. Tensions for green criminology. Critical Criminology, 25(2), 311-323. 
Brisman, A., and South, N., 2018. Green criminology, zemiology, and comparative and inter-relational justice in the Anthropocene era. In: A. Boukli and J. Kotzé, eds., Zemiology. Cham: Palgrave Macmillan, 203-221.

Bryant, B., ed., 1995. Environmental Justice: Issues, Policies, and Solutions. Washington, DC: Island Press.

Bullard, R.D., 1994. Overcoming racism in environmental decision making. Environment: Science and policy for sustainable development [online], 36(4), 10-44. Available from: https://doi.org/10.1080/00139157.1994.9929997 [Accessed 21 March 2019].

Burger, M., 2003. Bi-polar and polycentric approaches to human rights and the environment. Columbia Journal of Environmental Law [online], 28, 383-384. Available from: https://doi.org/10.7916/D8Z60N7S [Accessed 21 March 2019].

Caballero, G., and Soto-Oñate, D., 2017. Environmental crime and judicial rectification of the Prestige oil spill: The polluter pays. Marine Policy [online], 84, 213-219. Available from: http://doi.org/10.1016/j.marpol.2017.07.012 [Accessed 21 March 2019].

Cabanes, V., 2017. Homo natura: En harmonie avec le vivant. Paris: Buchet/Chastel.

Cano, L., 2018. Rights of nature: Rivers that can stand in court. Resources [online], 7(1) 13. Available from: https://doi.org/10.3390/resources7010013 [Accessed 21 March 2019].

Cento Bull, A., and Lauge Hansen, H., 2016. On agonistic memory. Memory Studies [online], 9(4), 390-404. Available from: https://doi.org/10.1177\%2F1750698015615935 [Accessed 21 March 2019].

Cohen, S. 2001. States of Denial: Knowing about Atrocities and Suffering. Cambridge: Polity Press.

Davies, P., 2018. Environmental crime, victimisation, and the ideal victim. In: M. Duggan, ed., Revisiting the "Ideal Victim": Developments in Critical Victimology. Bristol: Policy Press, 175.

Davies, P.A., 2017. Green crime, victimization and justice: A rejoinder. Critical Sociology [online], 43(3), 465-471. Available from: https://doi.org/10.1177/0896920516689071 [Accessed 21 March 2019].

Di Ronco, A., Allen-Robertson, J., and South, N., 2018. Representing environmental harm and resistance on Twitter: The case of the TAP pipeline in Italy. Crime, Media, Culture [online]. Available from: https://doi.org/10.1177/1741659018760106 [Accessed 21 March 2019].

Diz Otero, I., and Lois González, M.I., 2005. La reconstrucción de la sociedad civil en Galicia: la catástrofe del Prestige y el movimiento Nunca Máis. Revista de Estudios Políticos [online], no. 129, 255-280. Available from: https://dialnet.unirioja.es/descarga/articulo/1317867.pdf [Accessed 21 March 2019]. 
Drumbl, M.A., 1998. Waging war against the world: the need to move from war crimes to environmental crimes. Fordham International Law Journal [online], 22(1), 122. Available from: https://ir.lawnet.fordham.edu/ilj/vol22/iss1/3/ [Accessed 21 March 2019].

Duncan, J.S., and Ley, D., 2013. Place/culture/representation. London: Routledge.

Feinberg, J., 1987. Harm to Others (Vol. 1). Oxford University Press.

Flynn, M., and Hall, M., 2017. The case for a victimology of nonhuman animal harms. Contemporary Justice Review [online], 20(3), 299-318. Available from: https://doi.org/10.1080/10282580.2017.1348898 [Accessed 21 March 2019].

Gibbs, C., et al., 2009. Introducing conservation criminology: Towards interdisciplinary scholarship on environmental crimes and risks. The British Journal of Criminology [online], 50(1), 124-144. Available from: https://www.jstor.org/stable/43612851 [Accessed 21 March 2019].

Groombridge, N., 1998. Masculinities and crimes against the environment. Theoretical Criminology [online], 2(2), 249-267. Available from: https://doi.org/10.1177/1362480698002002006 [Accessed 21 March 2019].

Hadden, J., 2015. Networks in Contention: The Divisive Politics of Climate Change. Cambridge University Press.

Haldemann, F., and Unger, T., eds., 2018. The United Nations Principles to Combat Impunity: A Commentary. Oxford University Press.

Hall, M., 2013. Victims of Environmental Harm: Rights, Recognition and Redress under National and International Law. London: Routledge.

Hall, M., 2014. Environmental harm and environmental victims: Scoping out a "green victimology". International Review of Victimology [online], 20(1), 129-143. Available from: https://doi.org/10.1177\%2F0269758013508682 [Accessed 21 March 2019].

Hall, M., 2017. Exploring the cultural dimensions of environmental victimization. Palgrave Communications [online], 3. Available from: https://doi.org/10.1057/palcomms.2017.76 [Accessed 21 March 2019].

Hall, M., 2018. Environmental victimisation: corporate villainy or state connivance? Radical Criminology [online]. Available from: http://eprints.lincoln.ac.uk/15918/ [Accessed 5 May 2018].

Hall, M., and Varona, G., 2018. La victimología verde como espacio de encuentro para repensar la otredad más allá de la posesión. Revista de Victimología/Journal of Victimology [online], 7, 107-128. Available from:

http://www.huygens.es/journals/index.php/revista-devictimologia/article/view/118 [Accessed 21 March 2019].

Halsey, M., 2004. Against "green" criminology. British Journal of Criminology [online], 44(6), 833-853. Available from: https://doi.org/10.1093/bjc/azh068 [Accessed 21 March 2019].

Hamilton, M., 2017. Restorative justice conferencing in an environmental protection law context: apology and corporate offending. Internet Journal of Restorative Justice, 
5 Year Celebration Special Issue [online], 2056-2985. Available from:

https://www.theogavrielides.com/product-page/the-potential-of-restorativejustice-in-strengthening-corporate-governance-frame [Accessed 20 March 2019].

Harari, Y.N., 2018. 21 Lessons for the 21 ${ }^{\text {st }}$ Century. London: Penguin.

Higgins, P., 2010. Eradicating Ecocide: Laws and Governance to Prevent the Destruction of Our Planet. London: Shepheard-Walwyn.

Hillyard, P., and Tombs, S., 2017. Social harm and zemiology. In: A. Liebling, S. Maruna and L. McAra, eds., The Oxford Handbook of Criminology. $6^{\text {th }}$ ed. Oxford University Press, 284-305.

Hoondert, M., Mutsaers, P., and Arfman, W., eds., 2018. Cultural Practices of Victimhood. London: Routledge.

IPCC (with R.T. Watson, M.C. Zinyowera and R.H. Moss, eds.), 1997. The Regional impacts of climate change: An assessment of vulnerability. A special report of IPCC working group II. Cambridge University Press.

Johnson, D.S., 2017. The status of green criminology in victimology research. McNair Scholars Research Journal [online], 10(1), 8. Available from: https://commons.emich.edu/mcnair/vol10/iss1/8/ [Accessed 21 March 2019].

Juste, J., 2003. La catástrofe del Prestige: Implicaciones internacionales. Política exterior, 17(92), 151-164.

Kauzlarich, D., Matthews, R.A., and Miller, W.J., 2001. Toward a victimology of state crime. Critical Criminology [online], 10(3), 173-194. Available from: https://link.springer.com/article/10.1023/A:1015744304749 [Accessed 21 March 2019].

Kirby, P., and O'Mahony, T., 2018. Identifying an emerging paradigm: Towards ecosocialism?. In: P. Kirby and T. O'Mahony, eds., The Political Economy of the LowCarbon Transition. Cham: Palgrave Macmillan, 231-258.

Kirchhoff, J., Strack, M., and Wagner, U., 2013. The needs of victims: An empirical categorization based on interpersonal conflicts. Journal of Social and Political Psychology [online], 1(1), 29-50. Available from:

https://doi.org/10.5964/jspp.v1i1.44 [Accessed 21 March 2019].

Lacey, N., and Pickard, H., 2018. A dual-process approach to criminal law: victims and the clinical model of responsibility without blame. Journal of Political Philosophy [online]. Available from: https://doi.org/10.1111/jopp.12160 [Accessed 21 March 2019].

Liboiron, M., 2018. The What and the Why of Discard Studies [online]. Available from: https://discardstudies.com/2018/09/01/the-what-and-the-why-of-discard-studies/ [Accessed 27 March 2019].

Liodakis, G., 2018. Capital, economic growth, and socio-ecological crisis: a critique of de-growth. International Critical Thought [online], 8(1), 46-65. Available from: https://doi.org/10.1080/21598282.2017.1357487 [Accessed 21 March 2019]. 
Lynch, M., 1990. The greening of criminology: A perspective on the 1990s. Critical Criminologist, 2, 3-4.

Lynch, M.J., and Stretsky, P.B., 2003. The meaning of green: Contrasting criminological perspectives. Theoretical Criminology [online], 7(2), 217-238. Available from: https://doi.org/10.1177\%2F1362480603007002414 [Accessed 21 March 2019].

Mairal, G., 2008. Narratives of risk. Journal of Risk Research, 11(1-2), 41-54.

Mann, G., and Wainwright, J., 2018. Climate Leviathan. London: Verso Books.

Mazzucato, C., 2016. Rights of Victims, Challenges for Corporations: Project's First Findings. Milan: Università Cattolica del Sacro Cuore.

McGarry, R., and Walklate, S., 2015. Victims: Trauma, Testimony and Justice. London: Routledge.

Mythen, G., and McGowan, W., 2017. Cultural victimology revisited. In: S. Walklate, ed., Handbook of Victims and Victimology. London: Routledge.

NASA Global Climate Change (with H. Shaftel, ed.), no date. How Do We Know? [online]. Available from: https://climate.nasa.gov/evidence/ [Accessed 5 May 2018].

Nurse, A., 2017. Green criminology: shining a critical lens on environmental harm. Palgrave Communications [online], 3(1), 10. Available from: https://doi.org/10.1057/s41599-017-0007-2 [Accessed 21 March 2019].

Paul, K., 2017. International Monsanto Tribunal Calls for Human Rights Over Corporate Rights. Regeneration International [online], 26 April. Available from: http://www.regenerationinternational.org/2017/04/26/international-monsantotribunal-calls-human-rights-corporate-rights/ [Accessed 15 June 2018].

Pemberton, S., 2016. Harmful Societies: Understanding Social Harm. Bristol: Policy Press.

Pineault, E., 2018. From provocation to challenge: Degrowth, capitalism and the prospect of "socialism without growth", a commentary on Giorgios Kallis. Capitalism Nature Socialism [online], 1-16. Available from: https://doi.org/10.1080/10455752.2018.1457064 [Accessed 21 March 2019].

Pinker, S., 2011. The Better Angels of Our Nature: A History of Violence and Humanity. London: Penguin.

Puleo, A., 2018. Ecofeminismo: Para otro mundo posible. Madrid: Cátedra.

Richardson, B., 2017. Time and Environmental Law: Telling Nature's Time. Cambridge University Press.

Riechmann, J., 2017. ¿Vivir como buenos huérfanos? Ensayos sobre el sentido de la vida en el Siglo de la Gran Prueba. Madrid: Catarata.

Rivera, I., 2014. A modo de epílogo. Retomando el concepto de violencia estructural. La memoria, el daño social y el derecho a la resistencia como herramientas de trabajo. In: I. Rivera, coord., Delitos de los Estados, de los mercados y daño social: Debates en criminología crítica y sociología jurídico-penal. Barcelona: Anthropos. 
Rivers, L., 2012. Shareholder return: A “Nuremberg defence"? Ecocide and restorative Justice. Environmental Law \& Management [online], 24(1), 17-19. Available from: https://eradicatingecocide.com/wp-content/uploads/2012/06/Shareholder-Returna-Nuremburg-defence.pdf [Accessed 21 March 2019].

Rodríguez Goyes, D., and Sollund, R., 2018. Animal abuse, biotechnology and species justice. Theoretical Criminology [online], 22(3), 363-383. Available from: https://doi.org/10.1177\%2F1362480618787179 [Accessed 21 March 2019].

Rossner, M., 2011. Emotions and interaction ritual: A micro analysis of restorative justice. The British Journal of Criminology [online], 51(1), 95-119. Available from: https://doi.org/10.1093/bjc/azq075 [Accessed 21 March 2019].

Rothe, D.L., and Kauzlarich, D., 2017. We are all complicit: victimization and crimes of the powerful. In: S. Walklate, ed., Handbook of Victims and Victimology. $2^{\text {nd }}$ ed. London: Routledge, 358-363.

Ruggiero, V., 2013. The Crimes of the Economy: A Criminological Analysis of Economic Thought. London: Routledge.

Ruggiero, V., and South, N., 2010. Critical criminology and crimes against the environment. Critical Criminology, 18(4), 245-250.

Ruiz Rodríguez, L., 2003. Las catástrofes medioambientales y la aplicación de la ley penal en el espacio. Eguzkilore [online], no․ 17, 47-56. Available from: https://www.ehu.eus/documents/1736829/2174325/Eguzkilore+17.6+RUIZ.pdf [Accessed 21 March 2019].

Ryan, M.L., Foote, K., and Azaryahu, M., 2016. Narrating Space/Spatializing Narrative: Where Narrative Theory and Geography Meet. Columbus: Ohio State University Press.

Sampedro, V., 2003. Nunca Máis: la marea, el dique y el búnker. In: D. Fernández and E. Grau, eds., Anuario de movimientos sociales: la red en la calle: ¿cambios en la cultura de movilización? Barcelona: Icaria, 176-194.

Shiva, V., 2017. Ending a century of ecocide and genocide, seeding earth. Indigenous Policy Journal [online], 27(3). Available from: http://www.indigenouspolicy.org/index.php/ipj/article/view/419/409 [Accessed 21 March 2019].

Simonsen, K.M., 2017. The political agency of victims in atrocity tales by Bartolomé de las Casas: the Spanish origin of human rights. In: K.M. Simonsen and J. Ross Kjærgård, eds., Discursive Framings of Human Rights. Negotiating Agency and Victimhood. London: Routledge, 26-42.

Soler, R., 2017. El ecocidio: ¿crimen internacional? Boletín electrónico del Instituto Español de Estudios Estratégicos [online], 128, 1-14. Available from: http://www.ieee.es/Galerias/fichero/docs opinion/2017/DIEEEO1282017 Ecocidio RoselSoler.pdf [Accessed 21 March 2019].

Solnit, R., 2016. Hope in the Dark: Untold Histories, Wild Possibilities. $2^{\text {nd }}$ ed. Chicago: Haymarket Books. 
South, N., 2007. The "corporate colonisation of nature": Bio-prospecting, bio-piracy and the development of green criminology. In: P. Beirne and N. South, eds., Issues in Green Criminology. London: Willan, 230-247.

Taibi Cicaré, F.T., 2018. Green criminology y ejercicios de visualidad en la Habana: confusión, estados de negación y “orientales". Crítica penal y poder [online], 14. Available from:

http://revistes.ub.edu/index.php/CriticaPenalPoder/article/view/19975/23502 [Accessed 21 March 2019].

Tombs, S., and Whyte, D., 2015. Introduction to the special issue on "crimes of the powerful". The Howard Journal of Criminal Justice [online], 54(1), 1-7. Available from: https://doi.org/10.1111/hojo.12110 [Accessed 21 March 2019].

Tompkins, P., and Bird, C., 1973. The Secret Life of Plants: A Fascinating Account of the Physical, Emotional, and Spiritual Relations Between Plants and Man. New York: Harper \& Row.

United Nations Environment Programme, 2018. Assessing Environmental Impacts: A Global Review of Legislation [online]. Nairobi: United Nations. Available from: https://wedocs.unep.org/bitstream/handle/20.500.11822/22691/Environmental Im pacts Legislation.pdf [Accessed 21 March 2019].

Varona, G., forthcoming 2020. The contribution of ecofeminism to the criminological debate in Spain. In: S. Walklate et al., eds., The Emerald Handbook of Criminology, Feminism and Social Change. Bradford: Emerald.

Verdú, J., 2003. La catástrofe del Prestige: análisis desde el derecho internacional. Eúphoros [online], 6, 77-86. Available from: https://dialnet.unirioja.es/descarga/articulo/1181315.pdf [Accessed 21 March 2019].

Walklate, S., 2017. Conclusion: developing and agenda for a (critical) victimology. In: S. Walklate, ed., Handbook of Victims and Victimology. $2^{\text {nd }}$ ed. London: Routledge, 379384 .

Wattad, M.S.A., 2009. The Rome Statute and Captain Planet: What lies between crimes against humanity and the natural environment? Fordham Environmental Law Review [online], 19(2), 265-285. Available from: https://ir.lawnet.fordham.edu/cgi/viewcontent.cgi?article=1637 [Accessed 21 March 2019].

White, R., 2013. Crimes Against Nature: Environmental Criminology and Ecological Justice. London: Willan.

White, R., 2018. Green victimology and non-human victims. International Review of Victimology [online], 24(2), 239-255. Available from: https://doi.org/10.1177\%2F0269758017745615 [Accessed 21 March 2019].

White, R., and Kramer, R.C., 2015. Critical criminology and the struggle against climate change ecocide. Critical Criminology [online], 23(4), 383-399. Available from: https://doi.org/10.1007/s10612-015-9292-5 [Accessed 21 March 2019]. 
Whyte, D., 2017. Crime as a social relation of power: reframing the "ideal victim" of corporate crimes. In: S. Walklate, ed., Handbook of Victims and Victimology. $2^{\text {nd }}$ ed. London: Routledge, 333-347.

Wolin, S., 2008. Democracy Incorporated: Managed Democracy and the Spectre of Inverted Totalitarianism. Princeton University Press.

Zahara, A., 2018. Against risk perception: The deficit model and public understandings of risk. Discard Studies [online], 10 January. Available from:

https://discardstudies.com/2018/10/01/against-risk-perception-the-deficit-modeland-public-understandings-of-risk/[Accessed 21 March 2019].

Zimmerman, M.E., 1985. The critique of natural rights and the search for a nonanthropocentric basis for moral behavior. The Journal of Value Inquiry [online], 19(1), 43-53. Available from: https://doi.org/10.1007/BF00151415 [Accessed 21 March 2019].

\section{Legal sources}

Convention on Access to Information, Public Participation in Decision-making and Access to Justice in Environmental Matters [also known as the Aarhus Convention] (online). United Nations Economic Commission for Europe. Aarhus, 25 June 1998.

Available from:

https://www.unece.org/fileadmin/DAM/env/pp/documents/cep43e.pdf [Accessed 21 March 2019].

Directive 2004/35/CE of the European Parliament and of the Council of 21 April 2004 on environmental liability with regard to the prevention and remedying of environmental damage. Official Journal [online], L 143, of 30 April, 56-75. Available from: https://eur-lex.europa.eu/legalcontent/EN/TXT/HTML/?uri=CELEX:32004L0035 [Accessed 21 March 2019].

Directive 2012/29/EU of the European Parliament and of the Council of 25 October 2012 establishing minimum standards on the rights, support and protection of victims of crime, and replacing Council Framework Decision 2001/220/JHA. Official Journal of the European Union [online], 14 November 2012. Available from: https://eur-lex.europa.eu/legal-content/EN/TXT/HTML/?uri=CELEX:32012L0029 [Accessed 21 March 2019].

Treaty of Lisbon amending the treaty on European Union and the treaty establishing the European Community (2007/c 306/01). Official Journal of the European Union [online], C 306/1 of 17 December 2007. Available from: https://eurlex.europa.eu/legal-content/EN/TXT/?uri=celex\%3A12007L\%2FTXT [Accessed 21 March 2019].

\section{Case law}

Judgment of the European Court of Human Rights, Grand Chamber, of 28 September 2010. Mangouras v Spain (12050/04) [online]. Available from:

http://hudoc.echr.coe.int/eng?i=001-100686 [Accessed 21 March 2019]. 